\title{
HEPATITIS A OUTBREAK ASSOCIATED WITH A MOTHERS' DAY 'YUM CHA' MEAL, SYDNEY, 1997
}

David Lee, Margaret Ashwell, Mark Ferson, and Ian Beer

South Eastern Sydney Public Health Unit

\section{Jeremy McAnulty}

Communicable Diseases Branch

NSW Department of Health

This article describes the investigation of an outbreak of hepatitis A that occurred among 'yum cha' patrons at an eastern Sydney restaurant on Mother's Day, 1997.

\section{BACKGROUND}

In New South Wales, hepatitis A is notifiable by medical practitioners on clinical suspicion of acute viral hepatitis, and by laboratories on detection of $\operatorname{IgM}$ specific for hepatitis A virus (HAV). Hepatitis A, which is generally acquired by ingestion, ${ }^{1}$ has been linked to the consumption of raw, or improperly cooked, contaminated foods (such as oysters and salad), ${ }^{2,3}$ contaminated water, ${ }^{4}$ and food contaminated by infected food handlers. ${ }^{5}$

\section{THE OUTBREAK}

On 11 June 1997, staff of the Sydney Children's Hospital and the Prince of Wales Hospital notified the South Eastern Sydney Public Health Unit of three cases of suspected hepatitis A. All three had eaten a 'yum cha' meal at the same restaurant on Mothers' Day, 11 May 1997. Over the following week, laboratories and general practitioners notified further cases, who had eaten at the same restaurant on the same day.

On 12 June, the manager provided the details of 52 parties representing at least 372 patrons who had made dining reservations for 11 May. The aim of the ensuing epidemiological and environmental investigation was to determine the source of hepatitis A infection and prevent further cases.

\section{METHODS}

\section{Epidemiological investigation}

A case-control study was conducted using a standardised questionnaire that was administered by telephone. The questionnaire covered: demographics; number in party; time of meal; types of meat, seafood, noodles, vegetables, and desserts consumed; types and onset date of symptoms compatible with hepatitis A or gastroenteritis experienced after the meal; use of eating utensils, and use of restaurant toilets.

Cases were defined as: people who had eaten at the restaurant on Mothers' Day, developed serologically confirmed hepatitis A with onset between 26 May and 30 June 1997, and were notified by 9 July. Two cases were excluded because information on foods eaten was not available by the time of analysis.

\section{FIGURE 1}

DATE OF ONSET OF HEPATITIS A CASES ASSOCIATED WITH 'YUM CHA' MEAL, SYDNEY, NSW, MAY TO JUNE 1997

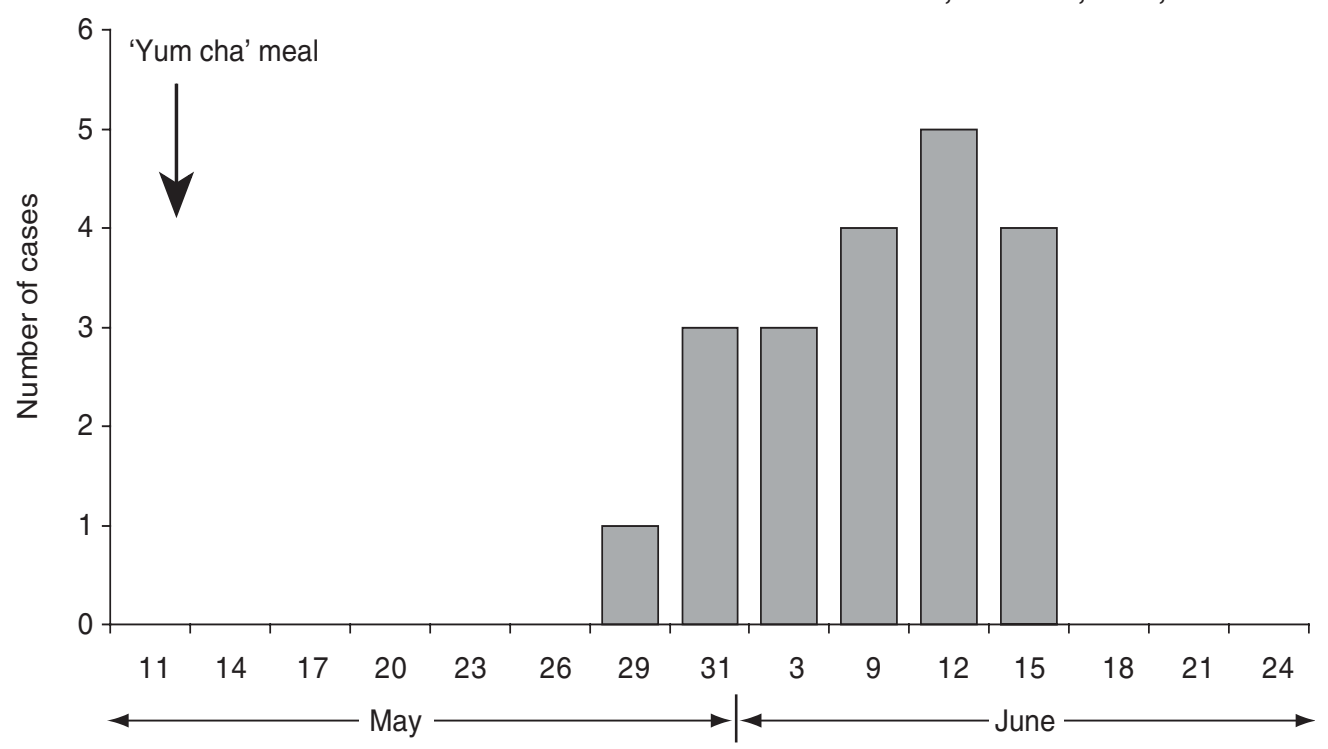

Date of onset of illness in intervals of three days

Source: South Eastern Sydney Public Health Unit 
Controls were: people selected from the reservation list who ate at the restaurant on Mothers' Day, who were contactable, and who had not developed symptoms of hepatitis A by the time of interview, between 17 and 19 June. Controls were not tested for hepatitis A.

Data were entered into and analysed using EpiInfo version 5. Statistical methods used were odds ratio (OR) with 95 per cent confidence intervals for comparison of exposures; two-tailed Fisher exact test where an expected value was less than 5; and the Kruskal-Wallis test for comparison of means.

\section{Environmental investigation}

On 12 June, food inspectors reviewed food-handling procedures at the restaurant and took samples of frozen shrimp, the only food that was served on Mothers' Day that remained. The manager provided a list of the food items served for 'yum cha' that day.

All of the 20 food handlers identified as having worked on Mothers' Day were tested for HAV-specific IgM and total antibodies.

\section{Microbiological analysis of shrimp}

Six samples of frozen shrimp were collected, comprising two leftover samples from the restaurant, and four other samples from the same shipment of shrimp meat still in storage with two suppliers. Samples were tested for bacteria using standard microbiological methods, and by polymerase chain reaction (PCR) for hepatitis A virus and enterovirus nucleic acid. ${ }^{6}$

\section{RESULTS}

\section{Epidemiological investigation}

Nineteen cases satisfied the case definition, 10 males and nine females, who were 7-52 years of age (mean 30 years). The first case became symptomatic on 29 May and the last became symptomatic on 9 June (Figure 1). The mean incubation period was 25 days, with a range of 18-29 days. Among the cases, symptoms were typical of acute hepatitis and included fever (90 per cent), nausea ( 84 per cent), dark urine (84 per cent), anorexia (74 per cent), jaundice (74 per cent), vomiting (63 per cent), abdominal pain (63 per cent), pale faeces (47 per cent), joint pain (42 per cent), and diarrhoea (37 per cent).

Of the 71 controls, there were 30 males and 41 females. Their ages ranged from three to 82 years of age (for two adults their age was unknown) with a mean age of 44 years. Controls were significantly older than cases (Kruskal-Wallis test, $\chi^{2}=8.6, d f=1, P<0.01$ ). There was no difference in sex distribution between cases and controls $(\mathrm{OR}=0.7,95$ per cent $\mathrm{CI}$ 0.2-2.1).

Controls began to eat between 9.30 a.m. and 2.00 p.m. and cases began to eat between 10.00 a.m. and 1.00 p.m., but there was no difference in the proportion who began to eat before 12.00 p.m. or later $(\mathrm{OR}=1.3,95$ per cent $\mathrm{CI}$ 0.4-4.1).

The case-control study indicated an association between eating shrimp and developing hepatitis A (OR undefined, two-tailed Fisher exact test $P=0.01$ ) (Table 1). All five who had eaten pork ribs had also eaten shrimp. There was no association between developing hepatitis $\mathrm{A}$ and having eaten steamed or fried noodles, various vegetables, or desserts. No case had eaten oysters.

Although for males, there was an association between using the restaurant toilet (used by both males and females) and developing hepatitis A (two-tailed Fisher exact test $P<0.005)$, there was no association for females $(P=0.24)$.

\section{Environmental investigation}

The restaurant had a seating capacity of around 200 patrons. Yum cha was served from 9.30 a.m. till about 2.00 p.m., with more than one sitting. On 11 May, 20 food handlers were reported to have worked as kitchen hands, waiters, or chefs. Their ages ranged from 21-55 years (mean 38 years). Six were females and 14 were males. All tested HAV-specific IgM negative and 18 (90 per cent) were total HAV antibody positive.

Each week, the restaurant received an average of six $16 \mathrm{~kg}$ cartons of frozen, raw, fresh-water shrimp. The shrimp used by the restaurant on 11 May were part of a shipment of approximately 10 tonnes imported from Myanmar (Burma) in late February. At the time of the investigation, frozen shrimp from the same shipment was still being distributed to various suppliers and restaurants. Neither the importer nor supplier kept records of batch numbers of shrimp that were sold to this restaurant.

\section{Microbiological analysis of shrimp}

The microbiological testing indicated low-level contamination with faecal coliforms and $E$. coli. In addition, two unusual Salmonella serotypes were isolated from two of the samples (Table 2). All samples were negative for hepatitis A virus, enterovirus, and Vibrio species.

\section{Control measures}

The South Eastern Sydney Public Health Unit contacted restaurant patrons, whose phone numbers were recorded in the reservation book, to advise them and their party members of the possible risk of hepatitis A. We also informed local hospitals and general practitioners of the outbreak, giving recommendations for contract tracing and prophylaxis. The NSW Department of Health issued a media release, in order to inform other restaurant patrons of the potential health risk and action to take. The manager voluntarily closed the restaurant. 
TABLE 1

FOODS CONSUMED BY HEPATITIS A CASES AND BY CONTROLS AT 'YUM CHA' MEAL, SYDNEY, NSW, 11 MAY 1997

\begin{tabular}{|c|c|c|c|c|c|c|}
\hline & \multicolumn{2}{|c|}{ Cases $(n=19)$} & \multicolumn{2}{|c|}{ Controls $(n=71)$} & \multirow[t]{2}{*}{ Odds ratio } & \multirow[t]{2}{*}{$(95 \% \mathrm{Cl})$} \\
\hline & $n$ & $\%$ & $n$ & $\%$ & & \\
\hline \multicolumn{7}{|l|}{ Seafood } \\
\hline Shrimp & 19 & 100.0 & 52 & 73.2 & $\infty$ & * \\
\hline Mussels & 1 & 5.2 & 5 & 7.0 & 0.8 & $(0.0-7.9)$ \\
\hline Calamari & 4 & 21.1 & 21 & 29.6 & 0.7 & $(0.2-2.6)$ \\
\hline Crab & 1 & 5.2 & 13 & 18.3 & 0.3 & $(0.0-2.2)$ \\
\hline \multicolumn{7}{|l|}{ Meat Dishes } \\
\hline Pork ribs & 5 & 26.3 & 3 & 4.2 & 8.7 & $(1.5-54.8)$ \\
\hline Chicken feet & 4 & 21.1 & 7 & 9.9 & 2.6 & $(0.5-12.2)$ \\
\hline Pork & 11 & 57.9 & 46 & 64.8 & 1.0 & $(0.3-3.5)$ \\
\hline Chicken & 8 & 42.1 & 40 & 56.3 & 0.7 & $(0.2-2.3)$ \\
\hline Beef & 3 & 15.8 & 21 & 29.6 & 0.5 & $(0.1-2.2)$ \\
\hline \multicolumn{7}{|l|}{ Other items } \\
\hline Oyster sauce & 9 & 47.3 & 23 & 32.4 & 2.4 & $(0.7-8.0)$ \\
\hline Lettuce & 2 & 10.5 & 4 & 5.6 & 2.1 & $(0.2-15.5)$ \\
\hline Egg custard & 4 & 21.1 & 16 & 22.5 & 1.0 & $(0.2-3.9)$ \\
\hline
\end{tabular}

\section{TABLE 2}

MICROBIOLOGICAL ANALYSIS OF SAMPLES OF SHRIMP MEAT ASSOCIATED WITH 'YUM CHA' MEAL, SYDNEY, NSW, 11 MAY 1997

\begin{tabular}{|lcccc|}
\hline Sample Source & SPC/g & Faecal coliforms/g & E. coli/g & Salmonella/25g \\
\hline Restaurant 1 & $1.2 \times 10^{8}$ & $<3$ & $<3$ & Not Detected \\
Restaurant 2 & $4.1 \times 10^{6}$ & 9 & 9 & S. hvittingfoss \\
Supplier A1 & $6.1 \times 10^{5}$ & $<3$ & $<3$ & Not Detected \\
Supplier A2 & $6.4 \times 10^{5}$ & 4 & $<3$ & Not Detected \\
Supplier A3 & $3.4 \times 10^{6}$ & $<3$ & $<3$ & S. paratyphi B var Java \\
Supplier B1 & $1.2 \times 10^{6}$ & 23 & 9 & Not Detected \\
\hline
\end{tabular}

$\mathrm{SPC}=$ standard plate count

Source: South Eastern Sydney Public Health Unit

\section{DISCUSSION}

This investigation found that the most likely cause of the outbreak was consumption of contaminated shrimp that were inadequately cooked. Shellfish implicated as a possible source of hepatitis A in the past have been raw oysters,,$^{2,7}$ and steamed or raw clams, ${ }^{7,8}$ but not shrimp.

$\mathrm{HAV}$ is viable for at least 10 days when stored at $-20^{\circ} \mathrm{C},{ }^{1}$ and for up to one month when stored dry at room temperature, ${ }^{9}$ and hence would survive in frozen shrimp. When experimentally suspended in phosphate buffered saline, HAV is inactivated by heating at $70^{\circ} \mathrm{C}$ for four minutes, at $75^{\circ} \mathrm{C}$ for 30 seconds, at $80^{\circ} \mathrm{C}$ for five seconds, or virtually instantaneously at $85^{\circ} \mathrm{C}$. However, HAV is inactivated in contaminated oyster and clam cockles once they have been cooked in water at $95^{\circ} \mathrm{C}$ for one-and-a-half minutes after their shells open. ${ }^{10}$
During cooking, the steamer baskets holding the delicately-parcelled dumplings of chopped shrimp are stacked, up to seven baskets high, over the boiler. As long as there is sufficient heat and water to maintain the flow of steam within the system, the cooking temperature should be relatively constant throughout the stack. However, environmental factors may hinder the core temperature from reaching the temperature required to inactivate the virus. Frozen food would require more time to reach the inactivation temperature than food held at room temperature. Other ingredients used in the preparation of the shrimp dumplings could insulate the virus from external heat. Also, pressure to serve more people than usual, as may have occurred on Mother's Day, may reduce the cooking time and so lower the core temperatures reached. ${ }^{2}$ 
It is unknown how these fresh-water shrimp were contaminated. The importer stated that they were harvested from a river in Myanmar, transported to a processor to be peeled, packed, and frozen for export. Shrimp from the same shipment were supplied to more than one restaurant in Sydney yet only one other patient who developed hepatitis A at the time of this outbreak reported having eaten a shrimp dish from a restaurant that bought from this shipment. It is possible that other recipient restaurants heated the shrimp sufficiently to inactivate HAV, or that only some shrimp in the shipment were contaminated with HAV.

In this outbreak, contamination by food handlers was unlikely, as those food handlers tested were either already immune or were negative for HAV IgM one month after the meal. However, it is possible that the manager may have overlooked casual staff. Finally, we considered the possibility that patrons infectious with hepatitis A may have contaminated the toilet door handle that other patrons then touched (the restaurant toilet was used by both male and female patrons). The analysis did not support this possibility, as there was no association between hepatitis A among female cases and use of the toilet. Possible explanations for why only 27 per cent of shrimp eating patrons interviewed developed hepatitis A are that: only some shrimp were contaminated; only some baskets were insufficiently cooked; or some patrons were already immune.

Shrimp may be a potential source of hepatitis A and should always be cooked properly. Only proper food handling and cooking will prevent foodborne hepatitis A.

\section{ACKNOWLEDGMENTS}

For assistance in this investigation, we thank: the staff of the Prince of Wales and the Sydney Children's Hospitals; the South Eastern Area Laboratory Services (SEALS)
Serology Laboratory, the South Eastern Sydney Public Health Unit, and the Division of Analytical Laboratories; the NSW Public Health Officers; and Dr Gary Grohmann, formerly of the University of Sydney School of Veterinary Pathology.

\section{REFERENCES}

1. MacCallum FO, Bradley WH. Transmission of infective hepatitis to human volunteers. Lancet 1944; 228.

2. Conaty S, Bird P, Bell G, Kraa E, Grohmann G, McAnulty JM. Hepatitis A in New South Wales, Australia, from consumption of oysters: The first reported outbreak. Epidemiol Infect 2000; 124: 121-130.

3. Lowry PW, Levine R, Stroup D et al. Hepatitis A outbreak on a floating restaurant in Florida, 1986. Am J Epidemiol 1989; 129: $155-164$.

4. Bloch AB, Stramer SL, Smith D et al. Recovery of hepatitis A virus from a water supply responsible for a common source outbreak of hepatitis A. Am J Public Health 1990; 80:428430.

5. Carl M, Francis DP, Maynard JE. Foodborne hepatitis A: recommendations for control. J Infect Dis 1983; 148:11331135.

6. Grohmann G. Viruses, food and environment. Foodborne microorganisms of public health significance. 5th edition. Sydney: Australian Institute of Food Science and Technology (NSW Branch), 1997; 603-620.

7. Koff RS, Grady GF, Chalmers TC, et al. Viral hepatitis in a group of Boston hospitals. New Engl J Med 1967; 276: 703710.

8. Berman HA, Waterman G, Fiumara J. Epidemiological notes and reports: shellfish-associated hepatitis-Massachusetts. MMWR 1972; 21: 20.

9. McCaustland KA, Bond WW, Bradley DW, Ebert JW, Maynard JE. Survival of hepatitis A virus in feces after drying and storage for 1 month. J Clin Microbiol 1982; 16: 957-8.

10. Millard J, Appleton H, Parry JV. Studies on heat inactivation of hepatitis A virus with special reference to shellfish. Epidemiol Infect 1987; 98: 397-414. H 